\title{
TTR
}

Traduction, terminologie, re?daction

\section{Beginnings of a European Project: Feminisms and Translation Studies}

\section{Luise von Flotow}

Volume 8, numéro 1, 1er semestre 1995

Orientations européennes en traductologie

URI : https://id.erudit.org/iderudit/037205ar

DOI : https://doi.org/10.7202/037205ar

Aller au sommaire du numéro

Éditeur(s)

Association canadienne de traductologie

ISSN

0835-8443 (imprimé)

1708-2188 (numérique)

Découvrir la revue

Citer cet article

von Flotow, L. (1995). Beginnings of a European Project: Feminisms and Translation Studies. TTR, 8(1), 271-277. https://doi.org/10.7202/037205ar d'utilisation que vous pouvez consulter en ligne.

https://apropos.erudit.org/fr/usagers/politique-dutilisation/ 


\section{Appendix}

\section{Beginnings of a European Project: Feminisms and Translation Studies}

\section{Luise von Flotow}

The relationship between feminist approaches to the history of ideas, to literary studies, to sociolinguistics, psycholinguistics and discourse analysis as well as to issues concerning language planning and policies has over the past twenty years been shown to be diverse, controversial and far-reaching. For, when aspects of language and communication are studied in the light of the gender differences which feminist scholarship has focussed on, characteristics once considered universal are often found to be specific to certain interest or power groups. The study of translation and interpretation not only incorporates all of the fields listed above; it is not only concerned with broad questions of universal or specific textual practices; it is also concerned with the daily work of transferring information, opinion, cultural developments, and in Europe, political policies, from one language into many others. The study of translation and interpretation is always also the study of the "ubiquity of translation" as José Lambert might put it. And one might expect the "ubiquity of gender differences" to enter into this study.

In Europe, some academic work is being done in the area of "feminism and/or gender and translation," yet there is much scope for further research. Feminisms as well as offshoots, such as gender studies, have yet to become institutionally sanctioned areas of research in many European universities, a factor which may be 
slowing academic development. Nonetheless, there are pockets of academics and practising translators/interpreters focussing on issues of gender and translation in a number of countries: I located them in Germany (Germersheim, Tübingen, Heidelberg), in England (Warwick, Bristol) and in Austria (Vienna), and there are doubtless others in the Scandinavian, Benelux, and Mediterranean areas. For the moment, the work of these groups is largely restricted to small internal colloquia or interdisciplinary courses offered for students at translation institutes, and is often focussed on a more general "women and language" or "gender and language" approach. Researchers' interests are diverse; formal publications on "gender and translation" are sparse or non-existent.

In the field of literary and scholarly publishing, feminist work is generally well-represented "in translation." Countless translations of recent Anglo-American and European feminist fiction, non-fiction and theory have appeared, suggesting strong public interest and intellectual "cross-pollination." Numerous feminist publishing houses have developed, The Women's Press and Virago in England; Frauen-offensive, Orlando Verlag and Frauenbuchverlag in Germany, Des femmes in France, and special series in the area of "gender studies" have been established in the more traditional houses, for instance, Suhrkamp/Frankfurt. Yet, corresponding activity in the academic institutions seems slow to reflect, or reflect on, the repercussions of what might be termed this popular public interest. European and North American feminist theorists of the last two decades may have problematized women's relationship to conventional "patriarchal" language; more recently, women scholars from developing nations added the dimension of "colonial" discourses to the issue, and feminist writers of fiction and non-fiction have continued to focus on the issue of language as an issue of power in their fictional writing. The work done at this level has, however, had wider public appeal than it appears to have raised research interests. There is still much work to be done to integrate "secondary," critical, synthesizing academic work on gender and language, and specifically on "gender and translation." 
Research that I circulated on the topic via translation studies networks met with a lot of interest but few defined research projects or publications: "work-in-progress" is what I found. Thus, instead of presenting what might be termed an overview of activities in the field in Europe, I can indicate what types of questions are being asked, indicate a number of research directions and make suggestions for further enquiries into the field. Questions and suggestions are derived in part from responses to my enquiries, and wherever appropriate I list the respondents.

The questions I posed to elicit information on scholarly projects in the area of gender and translation focussed largely on literary translation and read as follows:

Has feminist thought of the 1970s and 1980s had an influence on literary translation in Europe?

Have feminist theories of language or feminist "critique of patriarchal language" produced new theories of translation?

Have women translators become more gender-conscious? If so, how does this consciousness function in a translated text?

Have certain languages and literatures proven more receptive to feminist theories of language? Have certain genres proven more receptive than others?

Has gender-consciousness in language led to revisions of older translations of European literature or thought? To what effect?

How have literary critics responded to gender-conscious translation, if at all?

What remains to be done in the area of gender and translation studies in Europe? What are the prospects in the field? 
A few responses to these questions came from Poland, Germany, England, Switzerland and South Africa. I garnered further responses to gender and translation approaches at conferences, from direct contact with translation institutes, and through connections that came about through word-of-mouth. Herewith a summing up:

\section{Broad Historical Perspectives :}

. What roles have women played as translators?

. How have women authors fared in translation?

. How has gender itself been translated under certain ideological, social, cultural constraints? (Lori Chamberlain, via Mona Baker) ${ }^{1}$

\section{Contemporary Issues :}

\section{Feminist translation / Literary Translation:}

. What is the importance of contemporary philosophical enquiry for translation theory? (Susan Bassnett, Warwick) Is the "visible/invisible" translator dichotomy useful for gender-conscious translators? (Karin Littau, Bristol)

. How are feminist textual politics of texts transferred to other/hostile/welcoming cultures and languages - in children's literature, in adult literature, in popular writing, in journalism?

. What kinds of translation strategies are used to translate experimental feminist discourses - wordplay, sound association, irony, allusion? (Michel Harel, via Gideon Toury, Tel Aviv) What strategies are used to supplement "losses in translation" of feminist neologisms, syntactic innovation, metaphors, proverbs?

- Have translators become more gender-conscious? How are translators' feminist politics reflected in the target text? (Ursula Lang, Switzerland) What approaches do women translators use to deal with texts they find politically/culturally problematic?

1. Routledge Encyclopedia of Translation Studies, forthcoming in 1996/1997. 
. To what extent have contemporary gender-conscious retranslations of older works of literature or culturally important texts changed these works? (Jane Batchelor, Warwick)

. How is gender-conscious language in non-fiction texts translated into other target languages? (Marion Kremer, Hanover)

. To what extent do international popular culture/magazine texts addressed to women reflect gender-consciousness of respective target language/society?

. To what extent has public interest in gender created a market for translations, and for what kinds of texts? Which texts are translated, or left untranslated in Eastern Europe (Alicija Pisarska, Poznan, Poland), in Western Europe?

\section{European Union / Public Language Questions}

. To what extent have EU language policies/language planning/ translation policies taken gender into consideration?

- How have member countries translated/implemented these policies?

. How far do questions of gender enter into European Union questionnaires/surveys/opinion polls? (Janet Harkness, Mannheim) . Do translated handbooks on medical, technical, electronic subjects, travel guides, popular information texts reflect interest in gender?

. Are cross-cultural differences reflected in translations of medical/ pharmaceutical texts?

. What is the importance of gender difference in interpreting? Do male/female voices have different aural authority? To what extent and how does this authority depend on the specific situations?

. To what extent does gender difference affect the ability to switch codes? Does women's "oral culture" aid in interpreting skills? (A.C. Davis, Heidelberg)

. How far are different approaches to gender issues taken into account in the translation of audio-visual media in Europe?

These questions represent no more than the beginning of work on gender and translation in Europe; there are doubtless many more that could and should be asked. The attached bibliography of texts 
published in Europe or by European academics on the topic is included to give further impetus.

Luise von Flotow: ÉTI, Université d'Ottawa, 52 rue de l'Université, CP 450, Succ. A, Ottawa ON KIN 6 N5 (Canada)

\section{References}

BASSNETT, Susan (1992). "Writing in No Man's Land: Questions of Gender and Translation," Ilha Do Desterro, Studies in Translation, 28, pp. 63-73.

DIAZ-DIOCARETZ, Miriam (1985). Translating Poetic Discourse: Questions on Feminist Strategies in Adrienne Rich. Amsterdam, Benjamins.

GOGA, S.(1993). Emanzipation und weibliches Selbstverständnis In Charlotte Brontes "Jane Eyre" und ausgewählten deutschen Übersetzungen (masch. Diplomarbeit Düsseldorf).

HAREL, Michel (1993). La Transposition de l'"écriture féminine" du francais à l'hébreu. Mémoire de maîtrise, Univ. de Tel-Aviv.

JOUVE, Nicole Ward (1991). White Woman Speaks With Forked Tongue: Criticism as Authobiography. London, Routledge.

KEEFE, Terry (1994). "Another Silencing of Beauvoir. Guess what's Missing This Time?" French Studies, supp. no. 50, Spring, pp. 18-29.

KOSKINEN, Kaisa (1993). "Sexual/Textual Translation." Translation, the Vital Link. Proceedings, XIIIth World Congress, Brighton 1993, C. Picken, ed. London, Institute of Translation and Interpreting, vol. II, pp. 691-698. 
KRONTIRIS, Tina (1992). Oppositional Voices: Women as Writers and Translators of Literature in the English Renaissance. London $\&$ New York, Routledge.

PUSCH, Luise (1984). "'Eine männliche Seefrau! Der blödeste Ausdruck seit Wibschengedenken'- Über Gerd Brantenbergs Die Töchter Egalias," Das Deutsche als Männersprache. Frankfurt, Suhrkamp, pp. 69-75.

(1990). "Mary, please don't pun-ish us any more! Mary Daly, die Sprach und die deutschsprachige Leserin," Alle Menschen werden Schwestern. Frankfurt, Suhrkamp, pp. 104-111.

STARK, Suzanne (1993). "Women and Translation in the Nineteenth Century," New Comparison 15, Spring, pp. 33-44. 